\title{
Analisis Implementasi Pelaksanaan Pembelajaran Tatap Muka Terbatas di Masa New Normal
}

\author{
Lely Suryani ${ }^{1}$, Kristianus Jago Tuteh ${ }^{2}$, Maria Purnama Nduru ${ }^{3}$, Agnes Pendy ${ }^{4}$ \\ Pendidikan Matematika, Universitas Flores, Indonesia(1), Sistem Informasi, Universitas \\ Flores, Indonesia( ${ }^{(2)}$, Pendidikan Guru Sekolah Dasar, Universitas Flores, Indonesia( ${ }^{(3)}$ \\ DOI: $10.31004 /$ obsesi.v6i3.1915
}

\begin{abstract}
Abstrak
Penelitian ini dilatarbelakangi telah dilaksananakannya pembelajaran tatap muka terbatas sejak Juli 2021 melalui surat keputusan menteri pendidikan dan kebudayaan. Penelitian ini bertujuan untuk mengetahui implementasi pelaksanaan tatap muka terbatas di SDK Ende 8 dimasa new normal. Metode yang gunakan dalam penelitian ini adalah metode deskriptif kualitiatif. Teknik pengumpulan data dilakukan dengan teknik observasi, wawancara dan dokumentasi. Subjek dalam penelitian ini adalah 3 orang guru pada kelas 1 sekolah dasar. Hasil penelitian menunjukkan bahwa pelaksanaan pembelajaran tatap muka terbatas dapat dilaksanakan dengan baik dan sistematis serta perencanaan yang matang dengan mematuhi protokol kesehatan. Guru melaksanakan proses belajar mengajar di kelas sesuai dengan Rencana Pelaksanaan Pembelajaran yang disusun disesuaikan dengan kondisi new normal, pelaksanaan dengan cara memadatkan materi, menyampaikan point-point penting serta mempertegas pada penyelesaian latihan soal, begitu juga dengan evaluasi / penilaian guru melakukan ulangan harian, penilaian tengah semester dan juga penilaian akhir semester.
\end{abstract}

Kata Kunci: Pembelajaran tatap muka terbatas; sekolah dasar; new normal.

\begin{abstract}
This research was motivated by the implementation of limited face-to-face learning since July 2021 through a decree of the minister of education and culture. This study aims to determine the implementation of limited face-to-face implementation in SDK Ende 8 in the new normal. The method used in this research is descriptive qualitative method. Data collection techniques were carried out by observation, interview and documentation techniques. The subjects in this study were 3 grade 1 elementary school teachers. The results showed that the implementation of limited face-to-face learning could be carried out properly and systematically and with careful planning by complying with health protocols. The teacher carries out the teaching and learning process in class in accordance with the lesson plans that are prepared according to new normal conditions, implementation by condensing the material, conveying important points and emphasizing the completion of practice questions, as well as evaluation / assessment of teachers conducting daily tests, mid-semester assessments and as well as endof-semester assessments.
\end{abstract}

Keywords: Limited face-to-face learning; primary school; new normal.

Copyright (c) 2022 Lely Suryani, et al.

$\triangle$ Corresponding author :

Email Address : lelypane@gmail.com (Flores, Indonesia)

Received 3 June 2021, Accepted 19 November 2021, Published 2 January 2022 


\section{PENDAHULUAN}

Di Indonesia, dampak pandemi Covid 19 membuat dunia pendidikan harus berubah total, yang awalnya belajar dengan tatap muka berubah menjadi pembelajaran dari rumah (Maharani et al., 2021) (Aswat et al., 2021). Agar proses pembelajaran dapat tetap terlaksana dan tujuan pendidikan dapat tercapai, maka Menteri Pendidikan dan Kebudayaan Republik Indonesia mengeluarkan surat edaran yang menjelaskan mengenai proses belajar dan mengajar agar dapat dilakukan secara online atau daring dari tempat tinggal masing-masing (Dewi, 2020), yang bertujuan untuk mencegah dan memutus rantai penyebaran covid 19.

Pelaksanaan pembelajaran jarak jauh membutuhkan media yang dapat mendistribusikan ilmu pengetahuan atau sebagai wadah dalam proses kegiatan belajar mengajar. Media yang digunakan sebagai sarana pembelajaran jarak jauh sekarang ini menggunakan internet disebut juga dengan online learning yang dapat memberikan fasilitas koneksi keseluruh penjuru dunia. Internet yang tidak dibatasi jarak dan waktu membuat pembelajaran dapat dilakukan kapan saja dan dimana saja, penggunaan internet sebagai sarana belajar dapat memberikan dampak yang positif dalam penggunaan internet dengan peran para pendidik dalam pengelolahannya agar pembelajaran dapat terlaksana dengan efektif (Ismawati \& Prasetyo, 2020). Teknologi pembelajaran yang berbentuk platform seperti Zoom, Whatsapp Group, Youtube, Google classroom, E-Learning, dan sebaginya banyak dimanfaatkan untuk mengefektifkan proses pembelajaran Jarak Jauh (PJJ) (Habibah et al., 2020). Guru, orang tua dan siswa dipaksa harus bisa menggunakan teknologi-teknologi platform yang telah disepakati bersama pihak sekolah untuk digunakan dalam pembelajaran jarak jauh.

Di SDK Ende 8 pula, teknologi media pembelajaran yang berbentuk platform yang digunakan adalah Whatsapp Group. Sayang nya tidak semua orang tua memiliki smartphone yang dapat memenuhi standar yang diinginkan untuk pembelajaran ini serta masih banyak nya orang tua yang kurang mahir akan teknologi. Selain itu orang tua, tenaga kependidikan baik guru maupun dosen juga masih banyak yang belum juga menguasai teknologi pembelajaran dengan internet (Purwanto et al., 2020). Siswa juga mengalami kesulitan dalam pembelajaran jarak jauh ini, karena hal ini pertama kali mereka lakukan dalam proses pembelajaran. Semula mereka duduk di kelas dan Guru menerangkan di depan kelas, dan apabila mereka kurang mengerti, maka guru akan menerangkan lebih dalam sehingga mereka dapat mengerti materi yang sedang mereka pelajari. Ketika guru memberikan materi lewat teknologi platform seperti Whatsapp Group, mereka sulit untuk memahami dan sulit juga untuk bertanya kepada guru, sehingga pendampingan orang tua di rumah ketika mereka belajar sangatlah penting.

Wahyu et al., (2020) juga mengatakan bahwa dampak dari pandemi covid 19 yang dirasakan pada satuan pendidikan adalah kurangnya penguasaaan teknologi karena keadaan, sehingga mereka kesulitan dalam penerapan teknologi dalam kehidupan sehari hari. Fadilla et al., (2021) mengatakan bahwa problematika dalam pembelajaran jarak jauh ini adalah siswa sulit untuk memahami dan menguasai pembelajaran yang disampikan oleh guru secara online serta siswa kurang termotivasi untuk belajar. Hal serupa juga didapat dari hasil penelitian oleh Ode et al.,(2021) yang mengatakan bahwa pembatasan aktivitas belajar membuat tingkat pemahaman siswa terhadap materinya mengalami penurunan, ini karena alternatif pelibatan media pembelajaran online mengalami hambatan diantaranya kurang siapnya guru dalam pemanfaatan media, akses jaringan yang kurang memadai, ketersediaan kuota, terbatasnya kepemilikan smartphone, kurangnya pendampingan orang tua siswa, dan kurangnya pengalaman dalam pengelolaan kelas berbasis online. Peran orang tua dalam mendampingi kesuksesan anak selama belajar di rumah menjadi sangat ketat. Banyak panduan bagi orang tua dalam mendampingi putra-putri selama pandemi ini berlangsung yang meliputi tips pengasuhan agar lebih positif dan konstuktif dalam mendampingi anak selama beraktivitas di rumah. Orang tua pada awalnya berperan dalam membimbing sikap serta keterampilan yang mendasar, seperti pendidikan agama untuk patuh terhadap aturan, dan untuk 
pembiasaan yang baik namun perannya menjadi meluas yaitu sebagai pendamping pendidikan akademik(Kurniati et al., 2020).

Hasil Kajian Basar, (2021) membuktikan bahwa Pembelajaran Jarak Jauh dimasa Covid 19 menimbulkan perubahan pada sistem belajar mengajar yang mempengaruhi proses pembelajaran dan tingkat perkembangan peserta didik dalam merespon materi yang diberikan oleh guru. Menurut Dewi, (2020), oleh karena timbul banyaknya masalah dalam pembelajaran Jarak Jauh sehingga kualitas pendidikan di Indonesia dianggap mengalami penurunan maka pemerintah segera mengambil tindakan baru, yakni pembelajaran tatap muka terbatas yang dimulai pada Juli 2021. Akan tetapi, pembelajaran tatap muka terbatas memerlukan banyak kehati-hatian. Pembelajaran Tatap Muka Terbatas bisa dilaksanakan jika seluruh tenaga kependidikan telah melakukan vaksinasi serta mematuhi protokol kesehatan dengan 5M yaitu Memakai Masker, Mencuci Tangan, Menjaga Jarak, Menjauhi kerumunan dan Mengurangi mobilitas. Menurut (Pattanang et al., 2021) Ketika pembelajaran tatap muka akan dilakukan maka ada 3 hal yang sangat perlu di perhatikan yaitu peserta didik, pendidik dan tenaga kependidikan yang ada dilingkungan sekolah harus telah divaksin, meningkatkan imun tubuh serta sarana dan prasarana harus sesuai dengan protokol kesehatan.

Begitu juga hal nya dengan anak-anak usia dini terutama yang baru duduk di kelas 1 dan kelas 2 sekolah dasar pada umumnya masih sulit untuk menjaga jarak, mereka cendrung masih ingin bermain bersama teman-teman dan saling bersentuhan serta berpelukan. Ini karena anak-anak adalah generasi yang gemar besosialisasi dan aktif bermain. Oleh karena itu menjaga jarak adalah hal yang akan sulit untuk dilakukan. Peran guru dan orang tua untuk memberi pemahaman mengenai konsep menjaga jarak di tengah pandemi covid 19 ini sangatlah penting untuk mereka (Kurniati et al., 2020). Karena salah satu syarat untuk bisa pembelajaran tatap muka terbatas selain guru sudah vaksin adalah dengan 5M, yaitu Memakai Masker, Mencuci Tangan, menjaga Jarak, menjauhi kerumunan dan mengurangi mobilitas. Oleh karena itu penelitian ini bermaksud untuk melihat bagaimana Analisis Implementasi Pelaksanaan Pembelajaran Tatap Muka Terbatas di Masa New Normal khususnya bagi siswa yang duduk dikelas 1 Sekolah Dasar.

\section{METODOLOGI}

Metodologi dalam penelitian ini adalah deskriptif kualitatif. Proses analisis data penelitian kualitatif ini menggunakan proses analisis Miles dan Huberman 1992 yang menyatakan bahwa komponen analisis dibagi menjadi 3 yakni, reduksi data, penyajian data dan penarikan kesimpulan (Rijali, 2019) yang dapat dilihat pada gambar 1.

Penelitian ini dilaksanakan pada bulan Agustus sampai awal November 2021, yang bertujuan untuk menganalisis Pembelajaran Tatap Muka Terbatas di Masa New Normal khususnya bagi siswa kelas 1 Sekolah Dasar. Pada penelitian ini, data dan sumber data diambil dari siswa kelas IA sebanyak 19 orang, kelas 1B sebanyak 20 orang dan siswa kelas 1C sebanyak 21 orang di SDK Ende 8 tahun ajaran 2021/2022.

Teknik pengumpulan data menggunakan lembar observasi kegiatan pembelajaran tatap muka terbatas, lembar observasi aktivitas belajar siswa, wawancara, dan catatan lapangan. Lembar observasi kegiatan Pembelajaran Tatap Muka Terbatas (PTMT) diperuntukkan untuk mengumpulkan data pelaksanaan PTMT dengan mengacu pada langkah kegiatan aktivitas guru selama proses pembelajaran. Wawancara dan catatan lapangan digunakan untuk memperoleh informasi tambahan lainnya seputar hambatan pelaksanaan PTMT. Wawancara dengan guru kelas 1 dilakukan mendalam direkam dengan durasi wawancara antara 15-20 menit per orang. Teknik analisis data kualitatif dengan cara reduksi data, data display (penyajian data), dan conclusion drawing/verification (penarikan kesimpulan dan verifikasi) (Ode et al., 2021). Proses analisis data dan pedoman wawancara dapat dilihat pada gambar 1 dan tabel 1 dan 2. 


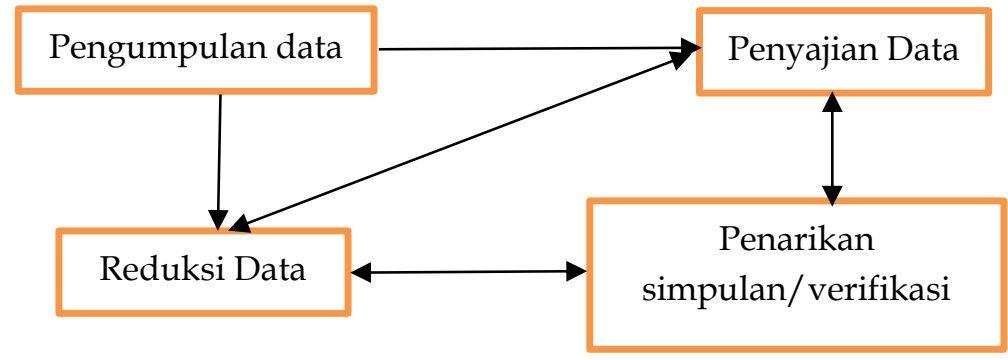

Gambar 1. Proses Analisis Data

Tabel 1. Pedoman Wawancara Guru

\begin{tabular}{|c|c|c|}
\hline \multirow{17}{*}{$\begin{array}{l}\text { Guru } \\
\text { Kelas } 1 \\
\text { SDK Ende } \\
8\end{array}$} & \multicolumn{2}{|r|}{ Pertanyaan } \\
\hline & 1 & $\begin{array}{l}\text { Sebelum TMT dimulai, apa yang harus dipersiapkan oleh sekolah dan siswa terutama } \\
\text { masalah protokol kesehatan sesuai surat edaran menteri pendidikan dan kebudavaan? }\end{array}$ \\
\hline & 2 & Sebelum TMT dimulai, apa yang harus dilakukan oleh sekolah dan siswa? \\
\hline & 3 & Apakah pembelajaran TMT sudah membantu proses kegiatan belajar mengajar? \\
\hline & 4 & Kesulitan apa yang ibu guru rasakan ketika melakukan TMT? \\
\hline & 5 & Bagaimana cara kerja ibu Guru dalam menyampaikan materai dari pembelajaran TMT? \\
\hline & 6 & Bagaimana cara ibu guru mengatasi kesulitan yang ada dalam kegiatan mengajar TMT? \\
\hline & 7 & Apa saja kelebihan dan kekurangan dari kegiatan pembelajaran TMT? \\
\hline & 8 & $\begin{array}{l}\text { Bagaimana pendapat ibu guru apabila pembelajaran TMT di lanjutkan hingga waktu } \\
\text { yang belum di tentukan? }\end{array}$ \\
\hline & 9 & $\begin{array}{l}\text { Apakah ibu guru memiliki cara atau metode baru yang di terapkan selama kegaitan } \\
\text { belajar mengajar TMT? }\end{array}$ \\
\hline & 10 & $\begin{array}{l}\text { Metode apa saja yang sekiranya mempermudah proses kegiatan mengajar yang ibu } \\
\text { guru lakukan? }\end{array}$ \\
\hline & 11 & $\begin{array}{l}\text { Apakah ibu Guru memiliki kendala dalam memberikan pemahaman materi pada siswa } \\
\text { ketika pembelajaran TMT? }\end{array}$ \\
\hline & 12 & $\begin{array}{l}\text { Apakah ibu guru mendapat dukungan dari sekolah mengenai kendala yang ibu guru } \\
\text { rasankan? }\end{array}$ \\
\hline & 13 & Hal apa saja yang tidak didapatkan pada pembelajaran TMT? \\
\hline & 14 & $\begin{array}{l}\text { Dari hal yang tidak didapat dalam pembelajarn TMT apa ada hal yang lain yang } \\
\text { menjadi masalah serius yang dihadapi oleh siswa kelas } 1 \text { ? }\end{array}$ \\
\hline & 15 & Apa yang dilakukan ibu guru untuk meminimalisir masalah yang ada? \\
\hline & 16 & Apakah pembelajaran TMT sudah membantu proses kegiatan belajar mengajar? \\
\hline
\end{tabular}

Tabel 2. Pedoman Wawancara Kepala Sekolah

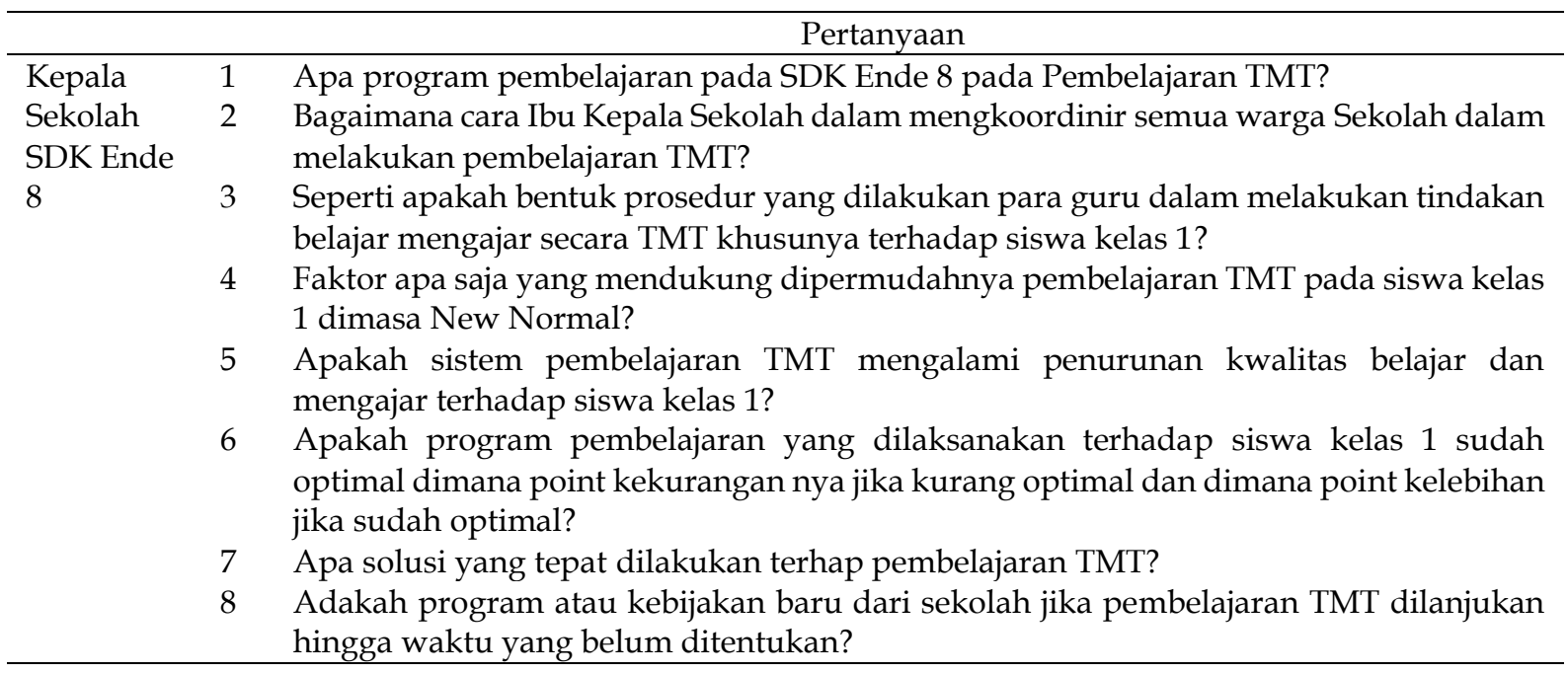




\section{HASIL DAN PEMBAHASAN}

Dimasa Pandemi ini, pendidikan harus terus berjalan, terutama pada anak usia dini kebutuhan anak akan belajar tentu menjadi alasan utama tetap dilaksanakan pembelajaran (Hutami \& Nugraheni, 2020). Pelaksaanan pendidikan di era new normal harus segera terlaksana, meskipun banyak pro dan kontra terjadi di masyarakat (Panjaitan et al., 2020). Walaupun sudah banyak dan hampir seluruh tenaga kependidikan sudah mendapatkan vaksin akan tetapi anak-anak usia dibawah 12 tahun belum bisa mendapatkan vaksin. Oleh karena itu untuk mencegah penyebaran rantai covid 19, kewaspadaan harus selalu di jaga.

\section{Pelaksanaan Protokol Kesehatan}

Pihak sekolah harus bekerja dengan ekstra agar suasana pembelajaran di kelas sesuai dengan protokol kesehatan 5M yakni, memakai masker, mencuci tangan, menjaga jarak, menjauhi kerumunan dan mengurangi mobilitas. Standar protokol kesehatan yang dilakukan dalam Kegiatan Belajar Mengajar (KBM) yaitu memasuki area sekolah harus memenuhi standar protokol kesehatan tersebut. Setiap guru memiliki peran masing-masing dalam melayani siswa di sekolah. Saat masuk gerbang sekolah siswa sudah di jamu oleh satu guru yang bertugas mengecek suhu badan siswa yang tidak boleh lebih dari $37^{\circ}$ Celsius. Anak harus dalam kondisi sehat jasmani, tidak sedang dalam kondisi demam, batuk, pilek, sesak nafas, wajib memakai masker selama berada di area sekolah. Setelah lolos standar cek suhu badan langsung cuci tangan di tempat yang telah disediakan.

Kegiatan ini dimaksudkan untuk menjaga kebersihan tangan siswa agar terhindar dari bahaya virus covid-19, karena virus akan mati jika terkena sabun. Menggosok tangan dengan sabun dan air sangatlah penting karena kombinasi ini menciptakan lebih banyak gelembung sabun yang mengganggu ikatan kimia yang memungkinkan bakteri, virus, dan kuman lainnya menempel di permukaan (Bramasta, 2020). Di sekolah juga menyiapkan masker jika ada siswa yang dari rumah lupa membawa masker dan hand sanitaizer

Setelah proses standar protokol kesehatan awal terpenuhi maka dilanjutkan dengan KBM yang dipandu oleh guru bidang tematik dan guru bidang studi dalam waktu yang ditentukan, dilarang berkerumun dan selalu menjaga jarak (Social Distancing) (Sit \& Assingkily, 2020) dengan berada di posisi duduk yang telah ditentukan dengan tanda yang diberikan pada area kelas. Posisi duduk dapat dilihat pada gambar 2.
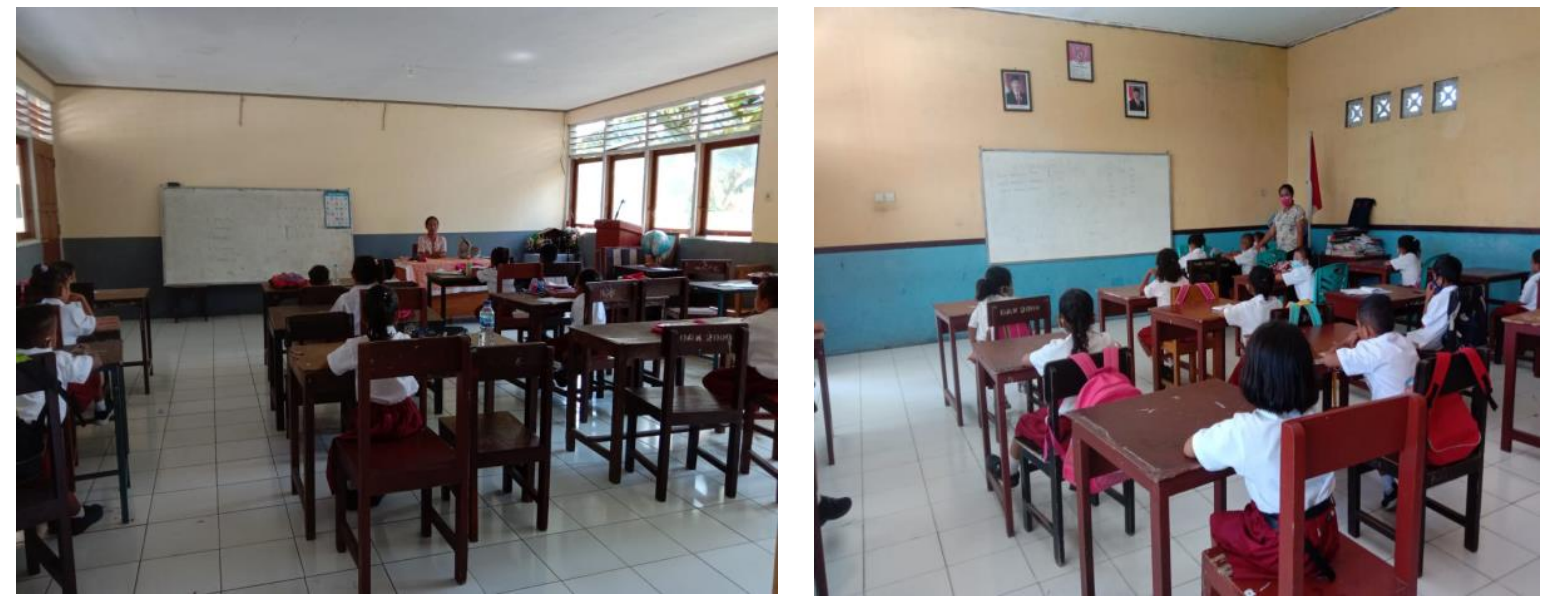

\section{Gambar 2. Social Distancing di Sekolah}

Selama KBM guru secara kontinyu memberikan hand sanitaizer untuk menjaga sterilisasi anak. Secara berkala pula dilakukan penyemprotan desinfektan dihari Sabtu, setelah proses belajar mengajar selesai. Hal ini berguna untuk mencegah covid 19. Bagi anak yang baru saja bepergian dari luar kota/wilayah, tidak diperkenankan mengikuti KBM selama 3 hari hingga dipastikan tidak timbul gejala covid-19. Bagi anak yang dilingkungan sekitarnya 
terdapat pasien positif covid-19 pula juga tidak diperkenankan mengikuti KBM selama 3 hari hingga dipastikan tidak timbul gejala covid-19.

\section{Implementasi Tatap Muka Terbatas}

Sesuai surat edaran Dinas Pendidikan dan Kebudayaan No. 420/04/60728 tentang penyelenggaraan KBM tatap muka tahun pelajaran 2021/2022. Sekolah yang berada di bawah naungan Dinas Pendidikan dan Kebudayaan, diperbolehkan melakukan pembelajaran tatap muka dengan ketentuan: (1) Masuk untuk semua kelas (I s.d III); (2) 1 jam pelajaran; (3) Istirahat 1 (satu) kali selama 15 menit, siswa tetap di dalam kelas; (4) 1 (satu) ruang maksimal 16 siswa; (5) Apabila siswa lebih dari 16, maka dibuat shift di hari berikutnya; dan (6) Jarak tempat duduk antar siswa minimal 1 meter.(Nissa \& Haryanto, 2020).

Dalam kegiatan pembelajaran, perencanaan menjadi awal proses sebelum pelaksanaan dan penilaian/evaluasi. Tujuan pembelajaran dapat tercapai dengan efektif dan efisien jika direncanakan dengan baik. Perencanaan yang dibuat dituangkan kedalam Rencana Pelaksanaan Pembelajaran (RPP). RPP mengacu pada silabus dan kurikulum yang berlaku, kemudian dikembangkan sesuai dengan kondisi di satuan pendidikan. RPP dimodifikasi sesuai dengan kebutuhan dan keperluan.

RPP pada satuan tingkat pendidikan Sekolah Dasar disusun berdasarkan tema/subtema dan KD yang dilaksanakan dalam satu atau lebih pertemuan. Guru akan merencanakan jumlah pertemuan dengan melihat muatan materi dan kegiatan yang dilakukan dalam pembelajaran. Kondisi pandemi Covid-19 ini, mengharuskan guru untuk membuat rencana pelaksanaan pembelajaran yang berbeda karena faktor keterbatasan waktu karena mengingat sekarang masih di masa pandemi.

Berdasarkan hasil wawancara dengan guru kelas I A. B dan C di SDK Ende 8, menyatakan bahwa kegiatan pembelajaran tatap muka saat pandemi Covid-19 berbeda dengan kondisi pada saat normal. Hal tersebut dibuktikan dengan durasi pembelajaran yang dipersingkat dengan cara memadatkan materi serta kegiatan pembelajaran hanya boleh dilakukan didalam kelas selain pembelajaran PJOK (Pendidikan Jasmani dan Olah Raga). Untuk itu guru dibimbing untuk menyusun RPP yang disesuaikan dengan kondisi saat ini, dengan cara pelatihan serta diskusi dalam Kelompok Kerja Guru sehingga tersusunlah RPP yang cocok digunakan pada saat pandemi covid-19. Hal ini sesuai dengan penelitian yang dilakukan oleh Dewi, (2020) yang menyatakan bahwa proses pelaksanaan belajar mengajar dimasa pandemi dilakukan denga cara menyampaikan materi cukup dipadatkan dan hanya menyampaikan materi yang penting saja dan mempertegas latihan soal karena dipacu oleh waktu. Selain itu hasil wawancara dengan kepala sekolah juga menjelaskan penyusunan RPP yang baik dan RPP yang dibuat sesuaikan dengan masa pandemi.
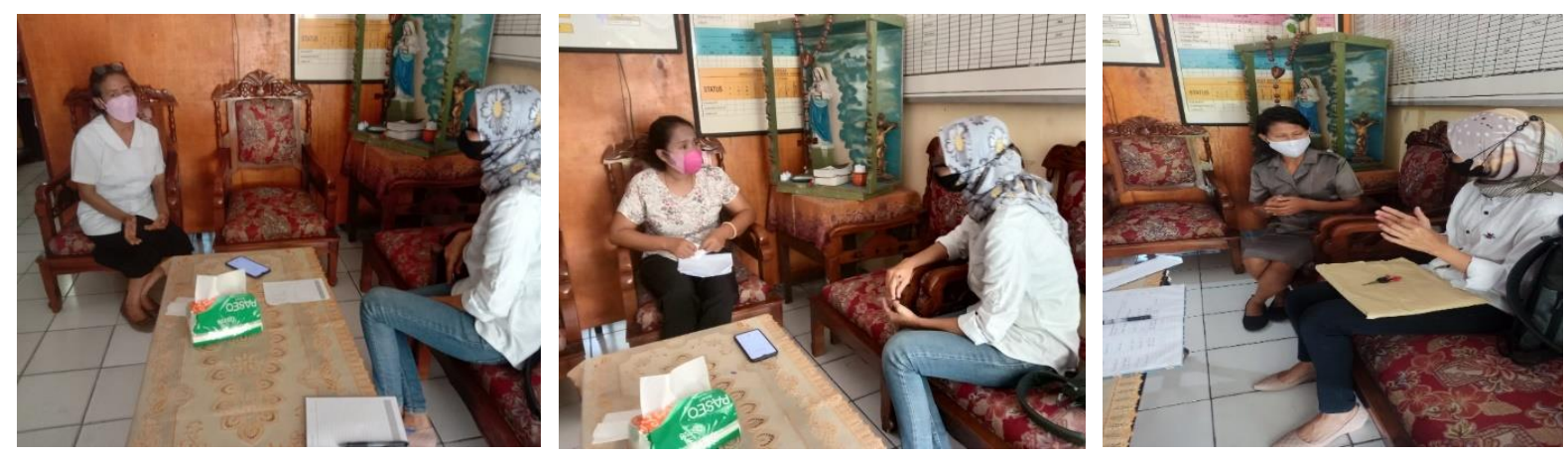

Gambar 3. Wawancara Dengan Guru Kelas dan Kepala Sekolah

Rencana Pelakasanaan Pembelajaran (RPP) yang telah dibuat guru secara mandiri, kemudian dijadikan pedoman dalam melaksanakan kegiatan pembelajaran di kelas sesuai dengan kondisi saat ini. Setelah tahap perencanaan kemudian masuk kedalam tahap 
pelaksanaan, dalam pelaksanaan pembelajaran guru membagi kelas menjadi 2 kelompok, yaitu kelompok A dan Kelompok B. Proses pembelajaran berlangsung normal, dan sesuai dengan alur RPP yang telah dibuat oleh guru.

Tabel 3. Jumlah kelas dan Nama Wali Kelas Kelas 1 SDK Ende 8

\begin{tabular}{lcc}
\hline Kelas & Jumlah & Nama Wali Kelas \\
\hline Kelas 1 A & 19 & Eutropia Mika \\
Kelas 1 B & 19 & Regina F Seku, S.Pd \\
Kelas 1 C & 21 & Maria Herlince, S.Pd \\
\hline
\end{tabular}

Tabel 4 Model Pembagian Kelas 1 SDK Ende 8 Dimasa Pandemi

\begin{tabular}{lcc}
\hline \multicolumn{1}{c}{ Kelompok } & Guru Tematik & Guru Bidang Studi \\
\hline Kelompok A & $07.15-8.30$ & $08.30-9.30$ \\
Kelompok B & $8.30-9.30$ & $07.15-08.30$ \\
\hline
\end{tabular}

Kelas 1 SDK Ende 8, terdiri atas 3 Kelas yang dapat dilihat pada tabel 3. Total keseluruhan siswa kelas 1 SDK Ende 8 ada 59 Siswa. Untuk memenuhi standar protokol kesehatan, maka kepala sekolah dan Guru-guru kelas 1 SDK Ende 8, memutuskan bahwa kelas 1 akan bersekolah pada hari Senin, Rabu dan Jumat dimana setiap kelas dibagi menjadi 2 kelompok yaitu kelompok A dan kelompok B, yang masing- masing kelompok terdiri dari 9 atau 10 siswa. Dapat dlihat pada tabel 4 bahwa apabila guru tematik berada di Kelompok A, maka di kelompok B akan mengajar guru Bidang Studi. Dimana Guru Bidang Sudi berjumlah 3 guru, yaitu guru Bahasa inggris, Guru PJOK dan Guru Agama. Pembagian Tiap kelas per Kelompok dapat dilihat tabel 5, 6, dan 7.

Tabel 5 Pembagian Kelas 1 A

\begin{tabular}{ccll}
\hline Hari & \multicolumn{1}{c}{ Kelompok } & \multicolumn{2}{c}{ Guru Bidang Studi/Guru Tematik } \\
\hline Senin & Kelas 1 A Kelompok A & $\begin{array}{l}\text { Guru Bidang Studi Bahasa } \\
\text { Inggris } \\
\text { Guru Tematik }\end{array}$ & Guru Tematik \\
& Kelas 1 A Kelompok B & $\begin{array}{l}\text { Guru Bidang Studi Bahasa } \\
\text { Inggris }\end{array}$ \\
Rabu & Kelas 1 B Kelompok A & Guru Bidang Studi PJOK & Guru Tematik \\
& Kelas 1 B Kelompok B & Guru Tematik & Guru Bidang Studi PJOK \\
Jumat & Kelas 1 C Kelompok A & Guru Bidang Studi Agama & Guru Tematik \\
& Kelas 1 C Kelompok B & Guru Tematik & Guru Bidang Studi Agama \\
\hline
\end{tabular}

Tabel 6 Pembagian Kelas 1 B

\begin{tabular}{ccll}
\hline Hari & \multicolumn{1}{c}{ Kelompok } & \multicolumn{1}{c}{ Guru Bidang Studi/Guru Tematik } \\
\hline Senin & Kelas 1 A Kelompok A & Guru Bidang Studi Agama & Guru Tematik \\
& Kelas 1 A Kelompok B & Guru Tematik & Guru Bidang Studi Agama \\
Rabu & Kelas 1 B Kelompok A & $\begin{array}{l}\text { Guru Bidang Studi Bahasa } \\
\text { Guru Tematik }\end{array}$ & \\
& & Inggris & Guru Bidang Studi Bahasa \\
& Kelas 1 B Kelompok B & Guru Tematik & Inggris \\
Jumat & Kelas 1 C Kelompok A & Guru Bidang Studi PJOK & Guru Tematik \\
& Kelas 1 C Kelompok B & Guru Tematik & Guru Bidang Studi PJOK \\
\hline
\end{tabular}

Selain tatap muka terbatas di sekolah, guru juga menggunakan aplikasi whatsapp. Aplikasi ini digunakan sebagai media tambahan untuk mengirimkan video pembelajaran dan untuk memberikan tugas kepada siswa yang akan dikerjakan di rumah. Tugas ini 
dimaksudkan agar siswa bisa belajar di rumah pada hari yang merupakan bukan jadwal tatap muka terbatas. Pekerjaan rumah tersebut akan dikumpulkan di hari berikutnya sesuia jadwal PTM. Hal ini bertujuan agar capaian pembelajaran yang ada di RPP tetap terpenuhi.

Tabel 7 Pembagian Kelas $1 \mathrm{C}$

\begin{tabular}{clll}
\hline Hari & \multicolumn{1}{c}{ Kelompok } & \multicolumn{2}{c}{ Guru Bidang Studi/Guru Tematik } \\
\hline Senin & Kelas 1 A Kelompok A & Guru Bidang Studi PJOK & Guru Tematik \\
& Kelas 1 A Kelompok B & Guru Tematik & Guru Bidang Studi PJOK \\
Rabu & Kelas 1 B Kelompok A & Guru Bidang Studi Agama & Guru Tematik \\
& Kelas 1 B Kelompok B & Guru Tematik & Guru Bidang Studi Agama \\
Jumat & Kelas 1 C Kelompok A & Guru Bidang Studi Bahasa & Guru Tematik \\
& & Inggris & Guru Bidang Studi Bahasa \\
& Kelas 1 C Kelompok B & Guru Tematik & Inggris \\
\hline
\end{tabular}

Tahap yang terakhir dalam pembelajaran yaitu tahap penilaian. Tahap penilaian proses belajar adalah upaya pemberian nilai terhadap kegiatan pembelajaran yang dilakukan oleh guru kepada peserta didik. Berdasarkan hasil pengamatan yang peneliti lakukan, setiap guru juga melakukan evaluasi, yaitu melakukan penilaian sikap dan penilaian materi seperti melaksanakan ulangan harian, Penilaian Tengah Semester (PTS) dan Penilaian Akhir Semester (PAS) seperti halayak umumnya. Dengan demikian setiap proses dalam pembelajaran tidak ada yang tertinggal, dari mulai perencanaan, pelaksanaan serta tahap evaluasi atau penilaian meskipun pada kondisi pandemi Covid-19.

\section{Kesulitan Tatap Muka Terbatas}

Dalam pelaksanaan tatap muka terbatas, dari hasil wawancara bersama guru kelas, masih ada kendala dalam hal capaian pembelajaran, yang dapat dilihat dalam kutipan wawancara terhadap Guru RFS.

Peneliti : "Kesulitan apa yang ibu guru rasakan ketika melakukan TMT?"

Guru A : "Dalam melaksanakan Tatap Muka Terbatas, ada beberapa hal yang kami rasa masih kurang maksimal diantaranya adalah waktu yang diberikan sangat pendek, sehingga saya kesulitan dalam menuntaskan materi, dan saya harus memadatkan materi sesuai dengan waktu yang diberikan."

Guru RFS juga menyatakan, langkah yang diambil dalam mengatasi kesulitan adalah:

“Apabila saya rasa tidak tuntas dalam pembelajaran di hari itu, maka saya dan guru lainnya akan memberikan tugas kepada anak-anak untuk di kerjakan di rumah sesuai kesepakatan kami bersama kepala sekolah. Ini agar capaian pembelajaran dapat tercapai walau tidak maksimal. Peran orang Tua terutama siswa kelas 1 dan kelas 2 harus tetap ada, sama seperti ketika pembelajaran Daring. Apabila ada pekerjaan rumah kami berikan, maka kami akan memberitahukan kepada orang tua melalui aplikasi Whatsapp, Kami menginginkan agar orang tua tetap mendampingi anak belajar dirumah agar pembelajaran dapat maksimal."

Selain itu, guru MH juga mengatakan bahwa :

"Untuk mengatasi kesulitan waktu tadi, kami juga mengirimkan video pembelajaran yang kami buat sendiri ke Whatsapp Group, dan meminta pendampingan orang tua dalam mempelajari video pembelajaran itu. Semua kami lakukan agar capaian pemelajaran yang diinginkan tercapai secara maksimal semampu kami".

Guru EM juga menambahkan bahwa, dalam pembelajaran Tatap Muka Terbatas lebih baik dibandingkan dengan daring, ini karena menurut narasumber bahwa pembelajaran dengan tatap muka lebih menimbulkan komunikasi dua arah secara aktif dengan siswa 
dibandingkan dengan daring. Dalam pembelajaran tatap muka terbatas Guru lebih dapat memahami siswa dan mengenal siswa dengan baik.

Kepala sekolah dalam hal ini yang bertanggung jawab terhadap jalannya pembelajaran di SDK Ende 8 menyatakan bahwa, SDK Ende 8 sudah berusaha secara maksimal dalam pelaksanaan Tatap Muka Terbatas, sesuai dengan Peraturan Menteri Pendidikan dan Kebudayaan pada bulan Juli 2021. Kekurangan dalam pembelajaran secara tatap muka terbatas di SDK Ende 8 menurut kepala sekolah adalah, waktu yang sangat singkat dan kelas dibagi menjadi 2 kelompok. Bentuk prosedur yang dilakukan dalam Tatap muka terbatas ini dibuat agar sesuai dengan peraturan menteri pendidikan dan kebudayaan mengenai social distancing. Ini karena kelas terdiri dari 19-20 siswa yang mana setiap kelas hanya bisa maksimal 16 siswa. Karena waktu yang terbatas dalam pemeblajaran tatap muka terbatas, maka Guru dituntut harus mampu membuat RPP yang disesuaikan dengan waktu dan dapat memadatkan materi agar semua capaian pembelajaran dapat di capai dalam pembelajaran Tatap muka terbatas ini. Kepala Sekolah mengkoordinir semua kegiatan TMT dengan cara membuat pertemuan mingguan dengan guru-guru untuk melihat sejauh mana perkembangan pembelajaran TMT dan a[pa yang harus dilakukan kedepannya agar semua capaian dalam pembelajaran dapat terpenuhi.

\section{Pembahasan}

Pada awal pandemi, pemerintah menerapkan prinsip memprioritaskan kesehatan dan keselamatan dalam penyelenggaraan pendidikan dengan mempertimbangkan tumbuh kembang anak dan hak anak selama pandemi. Kebijakan pembelajaran tatap muka terbatas secara bertahap mulai dilakukan untuk kembali meningkatkan kualitas belajar agar maksimal dan lebih terukur hasilnya (Kulsum, 2021). PTM Tebatas ini diyakini sebagai langkah penting dalam rangka menjaga kualitas pembelajaran anak indonesia dan sekaligus menjaga mental anak indonesia untuk kembali belajar luring (Sutriyanto, 2021). Apabila sekolah akan melakukan PTM Terbatas maka pihak sekolah harus maksimal dalam mempersipakan segala sesuatunya agar protokol kesehatan dalam PTM terbatas terpenuhi sebagai syarat utamanya.

Di SDK Ende 8, guru melakukan PTM Terbatas dan juga memberikan pekerjaan Rumah melalui media Whatsapp Group agar dapat diketahui orang tua dan orang tua diharapkan dapat membimbing anak untuk belajar dirumah. Ini karena dimasa pandemi ini orang tua adalah sebagai pembimbing, pendidik, penjaga dan pengembang serta pengawas di rumah (Hakim, 2020). Hal ini lakukan agar capaian pembelajaram tercapai. Ini karena singkatnya waktu yang bisa dilaksanakan selama PTM Terbatas disekolah, sehingga guru hanya memberikan materi pentingnya saja. PTM terbatas ini dianggap sangat membantu dalam hal menjaga pencapaian akademik anak-anak. Hal ini dikarenakan selama 1,5 tahun akibat Pandemi Covid 19, anak-anak harus belajar melalui PJJ dan dirasa kurang maksimal. Hal ini sejalan dengan paparan oleh Sri Wahyuni yang mengatakan bahwa "Studi menemukan bahwa pembelajaan dikelas menghasilkan pencapaian akademik yang lebih baik dibandingkan dengan PJJ" (Hendriyanto, 2021). Selain itu pembelajaran yang dilakukan selama Covid 19 dengan PJJ ini memberikan dampak terhadap psikologis anak. Kondisi pandemi dapat mebuat individu merasa tertekan dan khawatir, khususnya pada anak sekolah dasar. Dampak yang ditimbulkan antara lain ketidakstabilan emosi, reaksi stres, kecemasan, trauma dan gejala psikologis lainnya (Rosdiana \& Hastutiningtyas, 2021) .

Hal yang paling penting yang perlu dilakukan ketika PTM terbatas adalah secara psikologis anak. Agar mental anak siap dalam hal PTM Terbatas ini, maka hal pertama yang sekolah lakukan adalah memberi motivasi mengenai kesehatan dan bahayanya covid-19. Orang tua dan Guru harus memastikan bahwa anak-anak setiap harinya mematuhi protokol kesehatan sebelum memulai pembelajaran. Guru pula disekolah akan lebih mudah mengontrol kegitaan belajar mengajar yang terjadi hanya lebih kurang 2 jam sehari. Psikologis anak sangat penting dalam pembelajaran PTM terbatas ini dikarenakan lamanya berlangsung 
pembelajaran jarak jauh yang mempunyai dampak terhadap psikologis (Rosdiana \& Hastutiningtyas, 2021)

\section{SIMPULAN}

Pelaksanaan PTM terbatas dilakukan dengan perencanaan yang matang, dimulai dari penyusunan RPP yang dibuat sesuai dengan kondisi pandemi Covid-19, pelaksanaan pembelajaran yang diatur sesuai dengan rencana yang telah dibuat begitu pula dengan evaluasi atau penilaian. RPP dibuat guru secara mandiri, dengan pelatihan serta diskusi dalam Kelompok kerja guru sehingga tersusunlah RPP yang cocok digunakan pada saat pandemi covid-19. Pelaksanaan pembelajaran dilakukan dengan membagi shif kelas agar tidak menyalahi aturan Pemerintah dan proses pembelajaran tetap berlangsung. Pelaksanaan PTM terbatas cukup terarah, dan rutin melakukan evaluasi kegiatan. Kerjasama untuk membangun kesadaran serta komitmen antara guru dan orang tua sangat berkaitan erat agar PTM terbatas dapat berjalan sesuai dengan standar protokol kesehatan. Disiplin dalam melakukan protokol kesehatan disekolah dan melakukan monitoring serta evaluasi terhadap pelaksanaan PTM terbatas, dengan meminimalisir hambatan yang dialami selama kegiatan PTM terbatas berlangsung.

\section{UCAPAN TERIMA KASIH}

Pelaksaan penelitian ini tidak lepas dari bantuan bantiuan berbagai pihak, untuk itu kami mengucapkan rasa terimakasih yang sebesar-besarnya kepada Yayasan Perguruan Tinggi Flores, Lembaga Penelitian dan Pengabdian Masyarakat (LP2M) Universitas Flores, Program Study Pendidikan Matematika dan Sekolah Dasar Katolik Ende 8 terutama Kepala Sekolah dan Guru-Guru kelas 1 SD yang sangat berperan aktif dalam penelitian ini.

\section{DAFTAR PUSTAKA}

Aswandi. (2021). Pembelajaran Tatap Muka Terbatas. Untan.Ac.Id. https://www.untan.ac.id/pembelajaran-tatap-muka-terbatas

Aswat, H., Sari, E. R., Aprilia, R., Fadli, A., \& Milda, M. (2021). Implikasi Distance Learning di Masa Pandemi COVID 19 terhadap Kecerdasan Emosional Anak di Sekolah Dasar. Jurnal Basicedu, 5(2), 761-771. https://doi.org/10.31004/basicedu.v5i2.803

Basar, A. M. (2021). Problematika Pembelajaran Jarak Jauh Pada Masa Pandemi Covid-19. Edunesia: Jurnal Ilmiah Pendidikan, 2(1), 208-218. https://doi.org/10.51276/edu.v2i1.112

Dewi, W. A. F. (2020). Dampak COVID-19 terhadap Implementasi Pembelajaran Daring di Sekolah Dasar. Edukatif: Jurnal Ilmu Pendidikan, 2(1), 55-61. https://doi.org/10.31004/edukatif.v2i1.89

Fadilla, A. N., Relawati, A. S., \& Ratnaningsih, N. (2021). Jurnal jendela pendidikan. Jendelaedukasi.Id, 01(02), 48-60.

Habibah, R., Salsabila, U. H., Lestari, W. M., Andaresta, O., \& Yulianingsih, D. (2020). Pemanfaatan Teknologi Media Pembelajaran di Masa Pandemi Covid-19. Trapsila: Jurnal Pendidikan Dasar, 2(02), 1. https:// doi.org/10.30742/tpd.v2i2.1070

Hakim, F. N. (2020). Pola Relasi Anak dan Orangtua di Masa Pandemi Covid 19. PSISULA: Prosiding Berkala Psikologi, 2(1), 124-134.

Hendriyanto. (2021). Pembelajaran Tatap Muka Terbatas Sebagai Solusi di Masa Pandemi Covid-19.

Direktorat Sekolah

Dasar. https://ditpsd.kemdikbud.go.id/artikel/detail/pembelajaran-tatap-muka-terbatassebagai-solusi-di-masa-pandemi-covid-19

Hutami, M. S., \& Nugraheni, A. S. (2020). Metode Pembelajaran Melalui Whatsapp Group Sebagai Antisipasi Penyebaran Covid-19 pada PAUD di TK ABA Kleco Kotagede. 
Paudia: Jurnal Penelitian Dalam Bidang Pendidikan Anak Usia Dini, 9(1), 126-130. https:// doi.org/10.26877/paudia.v9i2.7023

Ismawati, D., \& Prasetyo, I. (2020). Efektivitas Pembelajaran Menggunakan Video Zoom Cloud Meeting pada Anak Usia Dini Era Pandemi Covid-19. Jurnal Obsesi : Jurnal Pendidikan Anak Usia Dini, 5(1), 665. https:// doi.org/10.31004/obsesi.v5i1.671

Kulsum, K. U. (2021). Pembelajaran Tatap Muka Terbatas: Urgensi dan Peneapannya. Kompas Pedia. https://kompaspedia.kompas.id/baca/paparan-topik/pembelajaran-tatapmuka-terbatas-urgensi-dan-penerapannya

Kurniati, E., Nur Alfaeni, D. K., \& Andriani, F. (2020). Analisis Peran Orang Tua dalam Mendampingi Anak di Masa Pandemi Covid-19. Jurnal Obsesi : Jurnal Pendidikan Anak Usia Dini, 5(1), 241. https:// doi.org/10.31004/obsesi.v5i1.541

Maharani, S., Majid, M., \& Yuhanna, W. L. (2021). Wisata Barokah : Alternatif Pembelajaran di Masa Pandemi Covid-19 di RA Al-Ikhlas Mantren. Jurnal Obsesi : Jurnal Pendidikan Anak Usia Dini, 5(2), 1676-1687. https://doi.org/10.31004/obsesi.v5i2.992

Nissa, S. F., \& Haryanto, A. (2020). Implementasi Pembelajaran Tatap Muka Di Masa Pandemi Covid-19. Jurnal IKA PGSD (Ikatan Alumni PGSD) UNARS, 8(2), 402. https:// doi.org/10.36841/pgsdunars.v8i2.840

Ode, L., Aswat, H., Sari, E. R., Meliza, NurOde, L., Aswat, H., \& Meliza, N. (2021). Analisis Pelaksanaan Pembelajaran Tatap Muka Terbatas (TMT) di Masa New Normal terhadap Hasil Belajar Matematika di Sekolah Dasar. Edukatif: Jurnal Ilmu Pendidikan, 3(6), 4400-4406.

Panjaitan, N. Q., Yetti, E., \& Nurani, Y. (2020). Pengaruh Media Pembelajaran Digital Animasi dan Kepercayaan Diri terhadap Hasil Belajar Pendidikan Agama Islam Anak. Jurnal Obsesi: Jurnal Pendidikan Anak Usia Dini, 4(2), 588. https:// doi.org/10.31004/obsesi.v4i2.404

Pattanang, E., Limbong, M., \& Tambunan, W. (2021). Perencanaan Pelaksanaan Pembelajaran Tatap Muka Di Masa Pandemi Pada Smk Kristen Tagari. Jurnal Manajemen Pendidikan, 10(2), 112-120. https:// doi.org/10.33541/jmp.v10i2.3275

Purwanto, A., Pramono, R., Asbari, M., Santoso, P. B., Wijayanti, L. M., Choi, C. H., \& Putri, R. S. (2020). Studi Eksploratif Dampak Pandemi COVID-19 Terhadap Proses Pembelajaran Online di Sekolah Dasar. EduPsyCouns: Journal of Education, Psychology and Counseling, 2(1), 1-12. https://doi.org/10.31932/ve.v12i1.835

Rijali, A. (20191). Analisis Data Kualitatif. Alhadharah : Jurnal Ilmu Dakwah.

Rosdiana, Y., \& Hastutiningtyas, W. R. (2021). Reaksi Psikologis Anak Belajar Daring (Online) Pada Masa Pandemi Covid-19 Di SDN Sumberejo 1 Purwosari Pasuruan. Nursing News : Jurnal Ilmiah Keperawatan, 5(1), 16-23. https:// doi.org/10.33366/nn.v5i1.2256

Sit, M., \& Assingkily, M. S. (2020). Persepsi Guru tentang Social Distancing pada Pendidikan AUD Era New Normal. Jurnal Obsesi : Jurnal Pendidikan Anak Usia Dini, 5(2), 10091023. https:// doi.org/10.31004/obsesi.v5i2.756

Sutriyanto, E. (2021). Pembelajaran Tatap Muka Terbatas Tekan Risiko Learning Loss, Tapi Keselamatan Nomor Satu. Tribunnews.Com. https:// www.tribunnews.com/pendidikan/2021/09/21/pembelajaran-tatap-mukaterbatas-tekan-risiko-learning-loss-tapi-keselamatan-nomor-satu

Wahyu, F. F., Nugraha, I. I., Pebrinsyah, M. I., \& Permadi, A. R. (2020). Dampak Corona dalam Dunia Pendidikan. Khazanah Pendidikan Islam, 2(3), 100-106. https://doi.org/10.15575/kp.v2i3.9905 